\title{
Monoclonal Antibody 1.4
}

National Cancer Institute

\section{Source}

National Cancer Institute. Monoclonal Antibody 1.4. NCI Thesaurus. Code C29196.

A monoclonal immunoglobulin G 1 (IgG1) antibody to murine leukemia virus (MuLV) 1.4.

( $\mathrm{NCl04)}$ 